\title{
6
}

\section{Destination World Heritage}

\section{World Heritage Convention}

The focus of the inquiry will now shift to World Heritage and to the temples of Abu Simbel and other sites. Focusing on World Heritage means that the inquiry's questions about the past and its history, memory, and heritage will now be given precise coordinates: why, then, identify, examine, document, protect, preserve, mediate, and also develop World Heritage? Is it not a Sisyphean - an absurd or meaningless - task to try to protect and preserve World Heritage for the unlimited future? So, why even bother to define a special category of World Heritage sites?

World Heritage sites are defined as monuments, buildings, and places of outstanding universal value which require protection and preservation for future generations. World Heritage may be cultural heritage, natural heritage, or a combination of both. World Heritage therefore represents both an idea and something concrete that can be visited.

In a world full of diversity and conflicts, where people are separated by gender, language, culture, history, religion, politics, and economics, the World Heritage List is an attempt at a common global perspective and a common global responsibility. In their encounter with World Heritage, human beings are expected to be part of humanity. As both an idea and a practice, World Heritage is therefore connected to the universalism of the Age of Enlightenment.

World Heritage sites have been chosen as Archimedean points to represent heritage globally, or, to use another metaphor, chosen as a main thread throughout this inquiry. There are several reasons for this choice. World Heritage sites form a well-defined category of cultural and natural heritage linked to clearly formulated justifications, criteria, and provisions for their proper use. World Heritage sites are found all over the globe, and they cover all periods and numerous types of monuments, buildings, locations, 
and landscapes. There is extensive but relatively accessible information at local, national, and international levels about the individual sites, providing facts, descriptions, criteria, protection details, and action plans. The information is available on the Internet and in numerous documents, reports, articles, and books. This makes it possible to compare sites, countries, and regions, to switch focus between individual sites and a broad global overview, and to move between the world of ideas and the material sphere. There is also extensive literature about World Heritage as a phenomenon - about its emergence and establishment and about the upholding of the Convention with its lists. Moreover, World Heritage as both an idea and a practice is surrounded by a debate in which dissimilar perspectives are represented. Once again, World Heritage sites are "good to think with" - and they are good to visit, too.

The roads to the adoption of UNESCO's Convention Concerning the Protection of the World Cultural and Natural Heritage (1972), also known as the World Heritage Convention, are described in many contexts. However, the content of these histories varies with the purposes and perspectives concerned. A point on which they diverge especially markedly is the question how far back in time the origins of the Convention are sought - back to 1965, 1959, 1945, 1919 , the 1870 s, 1789 , or the seventeenth century.

The shortest history was presented by persons involved in the creation of the Convention: two assistant directors-general of UNESCO, the engineer Michel Batisse and the lawyer Gérard Bolla. In L'invention du "patrimoine mondial" (2003) (English: The Invention of "World Heritage", 2005), they describe a heroic process in which international agents with different interests presented rival proposals that could finally be reconciled with the Convention as a compromise, a process in which they themselves played a crucial role. The synthesis, which placed protection of nature and of culture within the framework of one and the same convention, is highlighted as a diplomatic achievement; Batisse represented nature conservation and Bolla cultural preservation. They describe the proposal, put forward at a conference at the White House in Washington DC in 1965, for a "World Heritage Trust" to protect "natural and scenic areas and historic sites"; the International Union for Conservation of Nature and Natural Resources (IUCN), which proposed a similar trust in 1968; and UNESCO's own plans for cultural heritage. The solution, which was proposed at a UN conference on the human environment in Stockholm in 1972, was a convention with the name World Heritage, covering both culture 
and nature and including a fund. The World Heritage Convention was subsequently adopted in Paris on 16 November 1972.

The dominant account of the background to the World Heritage Convention places UNESCO in the centre and starts out from Abu Simbel. It appears in official contexts at UNESCO and its World Heritage Centre and in the literature about World Heritage and the Nubian campaign (e.g. Säve-Söderbergh 1987: 220f; Batisse 1992; 1996: 217f; Batisse \& Bolla 2003 (French): 97; 2005 (English): 92; World Heritage Information Kit, 2008: 7f; whc.unesco.org/ en/convention). The starting point is located at UNESCO's international campaign from 1959 to 1960 to salvage the temples and other threatened ancient monuments along the Nile. Even at this early date, a convention for the protection of cultural heritage is said to have been in preparation. Mention is also made of a stepby-step development with the UNESCO "Recommendation on the Safeguarding of the Beauty and Character of Landscapes and Sites" in 1962, the White House conference in 1965, the campaign spearheaded by UNESCO to save Venice after the floods in 1966, and the IUCN proposal of a World Heritage Trust in 1968. After a first draft presented at the UN Conference in Stockholm in 1972, experts from UNESCO, ICOMOS, and IUCN prepared the final convention proposal, which could be adopted in Paris that same year.

The background to the World Heritage Convention may also be followed back to the Second World War (e.g. Labadi 2013: 26ff). After the war's massive destruction and breakdown of the political order, developments restarted with new organisations. The UN and UNESCO were founded in 1945. And the Hague Convention for the Protection of Cultural Property in the Event of Armed Conflict (1954) laid down provisions for protection that stressed the cultural heritage and its protection as an international responsibility, as is evident in the following quotations: "the cultural heritage of all mankind" and "the preservation of the cultural heritage is of great importance for all peoples of the world and ... it is important that this heritage should receive international protection" (Hague Convention, 1954: 8).

The origins of the World Heritage Convention may be traced back to the experience of the First World War, in which many monuments were destroyed. There are accounts of a development that started with the League of Nations, which was founded in 1919; the formation of the International Museums Office; and a conference in Athens in 1931, which resulted in a first international resolution on the protection of historic monuments, the Athens Charter for 
Restoration of Historic Monuments (Titchen 1995: 12ff; Labadi 2007: 26ff; Cameron \& Rössler 2013: 1ff).

However, there were initiatives for protection and preservation across nations as early as the decades after 1870 , a period characterised by colonial great powers of which the British Empire was the greatest. Alongside a gradual professionalisation and the building up of protection and preservation at national level, there were also international contacts, especially in the Church, the universities, and the world of diplomacy (Hall 2011).

The emergence of antiquarian protection and preservation can also be traced back to the Enlightenment ideas of a public sphere and to reactions against the French Revolution in 1789. Here, too, there were international contacts and ambitions, as well as both cooperation and rivalry between the great powers of France, Britain, and Germany (Harrison 2013: 42ff; Swenson 2013).

It is, of course, possible to follow the idea of a canonised cultural heritage even further back in time. Initiatives involving ideas of protection during the wars of the seventeenth century form one example (e.g. Titchen 1995: 13f). So do earlier, more sporadic protection and preservation endeavours, such as preservation through reuse as spolia and the wonders of Antiquity that, in the eyes of that age, represented precisely the outstanding and universal.

The World Heritage Convention from 1972 has now itself become history, memory, and an intangible heritage. But what is it that is to be told, remembered, and preserved? Ideas about the Convention's origins vary with the individual commentator's purpose and choice of perspective. Narratives of its background provide an understanding and explanation of the establishment of the Convention, but they do more than that. For history-writing is not solely informative.

The various accounts of the Convention's gradual development, which was attended by difficulties that had to be overcome by means of diplomatic ingenuity and successful campaigns geared to averting threats against it, confer legitimacy both on the Convention in its present form and on UNESCO and the World Heritage Centre as managers of the Convention. This is, once again, a typical Whig writing of history, in which the Convention and, indirectly, its institutions are the self-evident goal of the developmental efforts.

\section{The Convention as innovation}

The World Heritage Convention belongs to the modern epoch with its optimism about progress and its universal ambitions in the wake 
of the Enlightenment. More specifically, ideas about a special category for global protection and preservation emerged gradually in the twentieth century, the salvage campaign for Abu Simbel forming an important milestone. They were realised with UNESCO's Convention Concerning the Protection of the World Cultural and Natural Heritage in 1972 (WHC 1972).

The practical management of the Convention is characterised by modernity, with a thorough bureaucratisation at the World Heritage Centre in Paris and (in principle) rational processes, criteria, and regulations. For instance, the Centre organises annual sessions as well as seminars and workshops, advises countries about nominations, organises financial and other support for World Heritage sites, updates the World Heritage List with the associated database, and develops educational materials. And the Centre itself is based in UNESCO's headquarters at Place de Fontenoy in Paris - a complex of buildings in glass and concrete from 1958, shaped like a three-pointed star, which radiates modern architecture of its period (cf. whc.unesco.org/en/world-heritage-centre).

World Heritage is a new concept, stemming from the idea of a particularly outstanding category of heritage that requires its own status, protection, preservation, and management. And World Heritage is an idea that has been transformed into a practical reality; that is, an innovation.

According to Michel Batisse, the World Heritage Convention has three central components that are perceived as innovative, both jointly and separately. The first is that places of "outstanding universal value" should be seen as a "common heritage". The second is the drawing up of the World Heritage List. And the third is that cultural and natural heritage are given equal standing. Then comes a fourth in the form of the concept of World Heritage itself (Batisse \& Bolla 2003 (French): 14ff; 2005 (English): 14ff).

However, national lists of monuments to be protected and preserved can be followed back to the legislation and inventories of the seventeenth century (cf. Jensen 2002: 325ff). The concepts of "common heritage", "universal value", and "universal protection" appear in the appeal made by UNESCO's Director-General Vittorino Veronese on behalf of the Nubian campaign in 1960 (Veronese 1960: 7). The word "outstanding" is not found in the appeal, but it contains a related phrase: "[w]ondrous structures, ranking among the most magnificent on earth". The concept of a "World Heritage Fund" was formulated by the lawyer Russell E. Train in Washington in 1965; but for linguistic reasons (there is no equivalent of "trust 
fund" in French) it had to be changed to World Heritage (Batisse \& Bolla 2003 (French): 17ff, 48, 98f; 2005 (English): 16f, 44, 94). The coordination of cultural and natural heritage was the final element to be put in place.

The concept of innovation comes from the Latin word innovare, which means "to renew" and originates from the word novus for "new". Innovations are new ideas, products, or methods that have also come into use. The words "innovation" and "modernisation" are partial synonyms. Innovations are thus something central, but not unique, to modernity.

Innovation is an extensive field of research in its own right where researchers have, for instance, worked on models for the chronological and geographical dissemination of new technologies. Particular inspiration is provided by the classic work Diffusion of Innovations (2003) by the sociologist Everett M. Rogers. On the basis of a great deal of empirical material, Rogers tried to systematise and generalise the course of the innovation process, examining when, where, and how innovations spread in social networks. According to Rogers, this development follows a bell-shaped curve when frequency is measured over time and an S-shaped curve when it is regarded as a cumulative process. He divided the agents involved in the process of innovation into five phases - innovators $(2.5 \%)$, early adopters $(13.5 \%)$, early majority (34\%), late majority (34\%), and laggards (16\%) (Rogers 2003).

Instead of analysing technical innovations such as tiles, clocks, phones, or tractors, the present discussion focuses on an international convention in which traces of the past are canonised. Inspired by Rogers, I wonder when, where, and how the World Heritage Convention was and is being disseminated as an idea and as a practice. Does it adhere to the same curve as other innovations? Who were the social agents involved in the process? Moreover, how was World Heritage as an innovation affected by criticism and by potential competition? And is World Heritage as an idea threatened by creative destruction, like other innovations?

On the basis of facts collected directly from UNESCO and the World Heritage Centre, World Heritage can be analysed as an innovation (Appendix 2). It is possible to follow how ever more countries ratify the Convention over time, and to identify the points in time when signatory countries are given their first World Heritage. In preparing and interpreting the statistics, account must be taken of the fact that the potential "market" grows over time with the formation of new states. There has thus been a striking increase in 
the number of UN member states that can accede to the Convention since 1972, when it was 132 countries, to the present number of 193 (whc.unesco.org/en/statesparties; September 2020).

The World Heritage Convention came into being in 1972; and the first country to ratify it, in 1973, was the US, which had also played a central role in the whole process (cf. Batisse \& Bolla 2003 (French): 32, 89; 2005 (English): 29, 85) - as one of the world's two superpowers at that time, serving as a model for others. In 1974, a further nine countries followed - Egypt (7 February), Iraq (5 March), Bulgaria (7 March), Sudan (6 June), Algeria (24 June), Australia (22 August), Democratic Republic of the Congo (23 September), Nigeria (23 October), and Niger (23 December). By the end of $1974,10(7.2 \%)$ of the UN's then 138 member states had ratified the Convention. The Convention was formally able to enter into force when ratified by 20 countries, and this number was reached with the accession of Switzerland in 1975. The first 20 countries hence created the necessary critical mass for the continued existence of the Convention.

It may be noted here that out of the first 10 ratifying countries, 6 were involved in UNESCO's salvage campaign in Nubia, either as hosts or as donors (cf. Säve-Söderbergh 1987: 232). Moreover, with these first 20 countries, all 5 inhabited continents were represented; that is, both the "old" and the "new" world.

If we follow Rogers, the innovators would be the first $2.5 \%$, a figure achieved with the accession of Bulgaria in March 1974. This would mean that four countries were the innovators - the US, Egypt, Iraq, and Bulgaria. But that would amount to interpreting the material in an overly formalistic way. In view of the differences in respect of administrative and political systems between these countries, it would be a mistake to attribute too much importance to a few months or a year here or there in the date of ratification.

In the course of the subsequent years, the number of countries ratifying the Convention remained relatively constant between 0 $(2008,2013,2015)$ and, at most, 10 (1975) new countries per year. Phase 1 (innovators, $2.5 \%$ ) was thus reached in 1974, phase 2 (early adopters, cumulative figure $16 \%$ ) in 1976, phase 3 (early majority, $50 \%$ ) in 1984, and phase 4 (late majority, $84 \%$ ) in 2000 , while phase 5 (laggards, up to $100 \%$ ) closed in 2020. More than $90 \%$ of UN member states had ratified the Convention by 2002 - and those ratifying thereafter are mostly small or new states like Swaziland (2005), Cook Islands (2009), South Sudan (2016) and then, most recently, Somalia (2020). The dissemination 
of the innovation over time may be described as relatively rapid, as $50 \%$ was attained a mere 12 years after the Convention came into being.

It is worth observing that France, as the seat of UNESCO and the World Heritage Centre, joined in 1975 in phase 2 while the Nordic countries, for instance, belong to phase 3 (Norway 1977, Denmark 1979) or phase 4 (Sweden 1985, Finland 1987, Iceland 1995).

At first sight, the innovation process would appear to be complete, since 193 states have ratified the World Heritage Convention and the UN has 193 member states. But these figures conceal a statistical complication. Three UN member states have still not ratified the Convention; they are Liechtenstein (1990, not a member of UNESCO), Nauru (1999), and Tuvalu (2000). By contrast, four other states that are not UN member states, but have observer status or are members of UNESCO, have ratified it; they are Niue (ratified in 2001), Cook Islands (2009), Holy See/ Vatican (2011, not a member of UNESCO), and Palestine (2011). All UNESCO's 195 member states have ratified the Convention. The last was Somalia, a country long ravaged by civil war, which ratified the convention in July 2020. Countries belonging to the group of "laggards" were not ignored; on the contrary, they have been the subject of special action to persuade all of them to join. Here it can be noted that Taiwan represented China up until 1971, but has not been a member of the UN or UNESCO since that time - and has therefore not been able to ratify the Convention either. But irrespective of how the counting is done, there is, in principle, global consensus about World Heritage. And no country has chosen to leave the Convention after signing it.

Statistical accounts of World Heritage sites generally present their growing number and much discussed geographical distribution across the world. Italy and China have the largest number with 55 each, followed by Spain with 48, Germany with 46, and France with 45. The regional distribution is Africa 96 (8.6\%), the Arab countries 86 (7.7\%), Asia and the Pacific 268 (23.9\%), Europe and North America 529 (47.2 \%), Latin America and the Caribbean $142(12.7 \%)$. Of the 193 states that have ratified the Convention, $26(13.5 \%)$ do not have a World Heritage (yet) - nor does Taiwan.

Social agents and networks have been and continue to be important, both formally and informally. Agents with their positions and contacts were crucial at the establishment of the World Heritage Convention, and they may continue to be so in future work on determining which heritages will be entered in the list. On the one 
hand, there is a formal process in which nations nominate a proposal for a coming World Heritage from tentative lists. This proposal is then assessed by the International Centre for the Study of the Preservation and Restoration of Cultural Property (ICCROM), ICOMOS, and IUCN, while UNESCO's World Heritage Committee makes decisions at its annual meeting of selected delegates. On the other hand, there is the work behind the scenes where individuals with their knowledge, personality, contacts, and lobbying may be of crucial importance for the success of a nomination, as may chance circumstances (e.g. Turtinen 2006).

The archaeologist Lynn Meskell has presented a chilling picture of how work in UNESCO with its World Heritage Committee is characterised by geopolitical intrigue, power-wielding states, alliances, rivalry, self-interest, and inconsistencies, in which small states and minorities are ignored, as are recommendations from UNESCO's own expert bodies. World Heritage is reduced to a cultural commodity in the international game (Meskell 2018).

As early as the salvage campaign for the temples of Abu Simbel, the importance of single individuals was in the foreground. Initiatives by named individuals - a minister of culture, an assistant director-general, an Egyptologist, and several others - are presented as heroes in the narrative of a sequence of events characterised by pressure of time and obstacles that had to be overcome (cf. SäveSöderbergh 1987: 64ff; 1996: 59ff).

However, what catches the eye in the literature about the salvage campaign and the establishment and administration of the Convention is how the texts are given legitimacy by a succession of forewords by individuals higher up in the hierarchy (e.g. DesrochesNoblecourt \& Gerster 1968: 7, 9), and how those involved either describe themselves as central agents or are so described by others. This is sometimes followed up by photographs showing those involved in single portraits, at gatherings, in meetings, or in front of monuments (e.g. Batisse \& Bolla 2003 (French): 47ff; 2005 (English): 43ff; Cameron \& Rössler 2013). In sumptuous publications, the forewords may also be accompanied by conspicuous portrait photographs (e.g. Anker \& Snitt 1997: 5, 8f). And in the media, politicians and high officials appear at the inauguration of a new World Heritage site, at the same time as the number of sites in the country concerned is apt to be noted with pride.

World Heritage sites are thus not only places to protect and preserve for the future, but also a capital that may yield a cultural, social, and political dividend for the countries, institutions, and 
individuals involved. There is prestige in being responsible for a World Heritage site. Publications about World Heritage sites are thus part of a social game about positions and memory, in which the agents try to associate themselves with valuable World Heritage. These agents cause themselves to be depicted in an endeavour to obtain a share of the outstanding and eternal - at least as its heroic defenders.

And no one is allowed to share this honour undeservedly. The evening before the reinauguration of Abu Simbel in 1968, UNESCO's Secretary-General discovered a memorial praising the efforts of the then President Abdul Nasser without mentioning UNESCO or its member states. In the face of the threat that the Secretary-General would not attend the ceremony, the memorial was speedily excised (Säve-Söderbergh 1996: 99; not mentioned in the English edition of 1987).

The interplay between the international, national, and local levels in the process of having a World Heritage site established may be followed in several studies. For instance, the establishment of the Hanseatic Town of Visby (WHL 731, 1995) and the Agricultural Landscape of Southern Öland (WHL 968, 2000), both in Sweden, is discussed in several articles and books, favourably by agents involved (Jonsson 2015) and more critically by researchers from the outside (e.g. Saltzman 2001: 205ff; Turtinen 2006: 140ff; Ronström 2007: 120ff). Another study of this kind of interplay concerns Angra do Heroismo on the Azores in Portugal (WHL 206; 1983; Johansson 2015). A third is a critical account of how Çatalhöyük in Turkey became a World Heritage site (WHL 1405, 2012; Meskell 2018: 134ff).

It is normal for new products to be met by criticism from consumers, and for producers to then try to improve their product so as not to lose market shares. World Heritage has not been reinvented, but it has been adjusted as an idea and a practice in relation to critical views. The management of the World Heritage Convention from 1972 has thus been changed over the nearly five decades that have passed: thematically new categories are constantly being added, culture and nature meet in mixed sites, new countries are included, national borders are crossed, more sites from a modern epoch have gradually been inscribed in the list, and attempts are made to redress any geographical or thematic imbalances (cf. WHL Filling, 2004).

In 1992, the World Heritage Convention was complemented by a scheme called the Memory of the World Programme, whose purpose 
was to protect and highlight particularly valuable documents or collections in archives and libraries. Since 1997 its Register includes, for example, Memory of the Suez Canal (1997), Declaration of the Rights of Man and of the Citizen (2003), Ingmar Bergman Archives (2007), Diaries of Anne Frank (2009), documents about TimorLeste, On the Birth of a Nation: Turning points (2013), and The Scientific and Mathematical Papers of Sir Isaac Newton (2015). The Register now consists of 427 memories in 118 countries (www. unesco.org/new/en/communication-and-information/memory-ofthe-world/homepage; Memory of the World, 2012; overview July 2019).

The traditional World Heritage is tangible, material, and frequently monumental. To complement this, UNESCO has defined a new category of intangible cultural heritage that is also to be protected for the future - "oral traditions and expressions", "performing arts", "social practices, rituals, and festive events", "knowledge and practices concerning nature and the universe", and "traditional craftsmanship". In 2003, the Convention for the Safeguarding of the Intangible Cultural Heritage (2003) was therefore put in place. So far, it has been ratified by $178(91.3 \%)$ of UNESCO's 195 member states (ich.unesco.org/en/convention; December 2019). The list includes, for instance, Vanuatu sand drawings (2008), Chinese calligraphy (2009), falconry (2010), the gastronomy of the French (2010), traditional carpet-weaving skills in Kashan in Iran (2010), and Fado singing in Portugal (2011). At the outset, in 2008, the list covered 90 instances of cultural heritage in 70 countries. The intangible cultural heritage items on the list have been divided into three categories: cultural heritage in urgent need of protection, the representative list, and good examples/good safeguarding practices. Now there are a total of 549 intangible cultural heritage elements in 127 (65.1\%) of member states (ich.unesco. org/en/lists; December 2019).

Can World Heritage as an idea and a practice be subjected to creative destruction just like other innovations, in other words be replaced by new and better solutions? This raises the question of what needs World Heritage is expected to meet.

The purpose of the World Heritage Convention is to select sites of particular value that are to be protected and preserved for future generations. But the idea of preservation is a phenomenon that arose in specific historical conditions. Protection and preservation became more important in the modern epoch from the end of the eighteenth century, and the concept of World Heritage belongs to 
the late twentieth century. It may be imagined that in the future, humanity will have other priorities, and that the protection and preservation of nature and culture will have to give way to other considerations; if nothing else, history demonstrates the importance of the unforeseen. World Heritage status may then become irrelevant.

So far, only two World Heritage sites have been removed from the list on account of other priorities. The first is the Arabian Oryx Sanctuary in Oman, which was delisted in 2007 when the protected area was reduced by $90 \%$ (WHL 654, 1994; delisted 2007). The second example is Dresden, where the construction of a new motorway bridge was thought to be more important than Dresden Elbe Valley as a World Heritage site (WHL 1156, 2004; delisted 2009). Here World Heritage had to give way to the latest manifestation of modernity.

The conditions for World Heritage may also become different if the present world community built up around the UN and its subsidiary organisations such as UNESCO is dissolved or replaced by something else. The UN is a historical construction both created and characterised by the victorious great powers after the Second World War. It is an organisation where states can meet, and it is neither better nor worse than its members - not necessarily democratic or effective when that might be desired. Its future is not selfevident. The known world community is changing. For example, both the US and Israel have withdrawn from UNESCO as of 31 December 2018.

The purpose of listing as a World Heritage site is protection and preservation for the future; but the outcome may be the opposite. Listing can give the site a status, attention, and an association to modernity which, contrary to its purpose, attracts destruction. Greater tourism may entail undesirable wear and tear, which antiquarian authorities try to regulate with plans for management. Furthermore, World Heritage status may also increase the risk of vandalism, as has already been seen in Mali and Syria, for example. Listing as a World Heritage site creates a well-defined target for attacks. But it is doubtful whether this means that agents will or should refrain from making nominations.

Since 1978, the World Heritage Centre has supplemented the World Heritage List with its own list which shows World Heritage sites that are in the danger zone for various reasons - World Heritage in Danger. Of the 1121 World Heritage sites, 53 (4.7\%) are in danger: they consist of 36 cultural and 17 natural World Heritage 
sites in $33(19.8 \%)$ of the 167 countries with World Heritage (whc.unesco.org/en/158; overview July 2019); and current war zones such as Congo, Iraq, Libya, Mali, Syria, and Yemen are abundantly represented.

Rogers has demonstrated an innovation paradox - that those who have least need of an innovation are the first to adopt it, whereas those who would have the greatest need show the greatest resistance and are among the last (Rogers 2003: 295f). But in the present context it is noteworthy that the war zones of our time, by contrast, acceded to the Convention at a relatively early date - Congo (1987), Iraq (1974), Libya (1978), Mali (1977), Syria (1975), and Yemen (1980).

If a regional or national ambition for World Heritage is to increase tourism and economic development, disappointed expectations may lead to reconsidered priorities. In the work to achieve World Heritage status, unrealistically high aims may easily be set. For instance, two decades after listing, it must be concluded that the Agricultural Landscape of Southern Öland (WHL 968; 2000) is perhaps unable to meet the great expectations for a peripheral rural district. Moreover, current plans for new windmills appear to collide with the status of the area - even though Öland does, in fact, have a long tradition of windmills.

If the purpose of the Convention, and of listing, is to protect, preserve, and make accessible, solutions other than physical preservation and restoration may also be considered in the years ahead. Digitalisation is rapidly gaining ground, so the future may bring schemes of "preservation" in the form of digital documentation that includes an experience using all the senses. Since 2003, for instance, World Heritage sites are documented in 3D as part of their preservation for the future (www.cyark.org).

Digital documentation may be a break with a traditional Western view of preservation and authenticity, but protection and preservation through transformation into documentation is nothing new; it is, for example, done all the time in archaeological excavations. And the Western view of authenticity as concrete material continuity is not the sole possibility given the "Asian" model, which stresses continuity in ideas and crafts, not the material dimension (cf. Larsen 1995; Labadi 2013: 113ff; Operational 2019: $\mathbb{\$}$ \$78ff).

But if the purpose of World Heritage is to define an exclusive heritage category in a reaction against the inflation in heritage, the constant increase in World Heritage sites must be a problem. The brand loses value if too many products are in circulation. The 
project of the seven new wonders of the world, New7Wonders, may be regarded as an attempt to re-establish an overarching category of excellence; but it has not succeeded in replacing World Heritage.

New7Wonders was founded by the filmmaker and museum curator Bernard Weber. The organisation wanted to contribute to creating a global and democratic memory with precisely seven wonders which everyone can remember, and which should be protected and preserved for the future. Global votes were used to select New 7 Wonders of the World (2000-2007), New 7 Wonders of the World Nature (2007-2011), and New 7 Wonders Cities (2011-2014) (www.new7 wonders.com).

The New 7 Wonders of the World were chosen on the basis of a list of 177 potential monuments. 77 of the 177 were nominated in a voting procedure. A panel of experts, headed by a former directorgeneral of UNESCO, then selected 21 finalists that went on to a vote in which around 100 million people took part. Most votes went to the Great Wall of China (WHL 438, 1987), Taj Mahal in India (WHL 252, 1983), Machu Picchu in Peru (WHL 274, 1983), Chichén-Itzà in Mexico (WHL 483, 1988), the statue of Jesus Christ at Rio de Janeiro in Brazil (WHL 1100rev, 2012), the Colosseum in Rome in Italy (WHL 91ter, 1980, 1990, 2015), and Petra in Jordan (WHL 326, 1985). After Egyptian protests, the pyramids in Giza (WHL 86, 1979) were given their own place of honour as the sole preserved site among the seven original wonders of Antiquity (www.new7wonders.com).

Not unexpectedly, voters chose much-visited tourist destinations and national monuments in populous countries which, with one exception, already had World Heritage status: the statue of Jesus Christ received it in 2012 (WHL 1100, 2012). Consequently, no great difference can be observed between what is accepted in UNESCO by national representatives and experts and what people think more generally. High culture and popular culture coincide, but the reason for that may be that the selection involved both experts and the general public. And both cases involve a democratic process - in the case of World Heritage representative democracy and in the case of New7Wonders direct democracy, at any rate in choosing between the finalists.

If inflation in heritage and World Heritage is a problem, UNESCO can put a ceiling on how many can be inscribed on the list. UNESCO can simply put a stop to more World Heritage sites - or not list any new ones unless old ones are removed - in 
brief, by prioritising. But at the moment there is no formal limit to the total number of World Heritage items that may be listed (cf. Operational 2019: \$58).

The 42 years in the period 1978-2019 saw the listing of 1121 sites of World Heritage, which amounts to an average of 26.7 new sites per year. UNESCO could, for instance, set a ceiling at a maximum of 1200 World Heritage sites, a figure that would, at the present rate, be reached in 2022, on the 50th anniversary of the Convention. But that kind of self-imposed restriction is probably impossible to apply in view of cultural-policy considerations, being attractive neither to individual UNESCO member states nor to the World Heritage Centre as an organisation.

\section{Outstanding, universal, and representative}

The World Heritage Convention has been ratified by virtually all countries, and after nearly five decades there are World Heritage sites everywhere on earth. World Heritage sites are spread across all continents with the exception of Antarctica and across variations in language, culture, history, religion, politics, and economics. The great popularity of World Heritage may be a cause of wonder wonder that a world deeply divided in many contexts is able to come together in the protection and preservation of an increasing number of monuments, buildings, places, and landscapes. What is it, then, that so many can agree on?

The core of the Convention, and the common denominator of all listed instances of World Heritage, is the requirement of "outstanding universal value" (e.g. Labadi 2013). This involves two different values that have to be fulfilled at the same time: a World Heritage site has to be assessed as being both outstanding and universal. By way of specification, the Operational Guidelines document (2019: $\$ 49, \$ 77)$ sets out ten criteria, at least one of which has to be met for listing as a World Heritage site. The guidelines also point out that "Nominations of immovable heritage which are likely to become movable will not be considered" (Operational 2019: \$48). However, the prior relocation was apparently not an impediment to nominating and listing the temples of Abu Simbel as part of a World Heritage site.

This shows us that the Convention and its World Heritage concept are dependent on a difficult balance; for the terms "outstanding" and "universal" may coincide, but they may also contradict each other. On the one hand, there is the assessment of the outstanding, 
pre-eminent, the superbly ingenious, or the excellent, and on the other, the assessment of the universal or general. The complication arises when the outstanding is not universal and the universal is not outstanding. The outstanding may be reserved for a few and the universal may be something that just does not stand out. A specification in ten criteria does not solve the problem; it merely moves the assessment to a different level. This does not address the fundamental difficulty, which is coming to an agreement about what is both outstanding and universal; that is, attaining a common human consensus about what is valuable in nature and culture.

My truth, beauty, and goodness need not be yours, too. My proposal for World Heritage does not need to be yours as well. What I see as outstanding and universal, you may reject as indifferent, provincial, or perhaps typically Western. When this is combined with questions of nationalism, identity, tourism, growth, and geopolitics, a chasm of potential conflicts opens up. If my or our World Heritage proposal is not accepted, then it is I, my people or country, my nature or culture, my nation, identity, development, and economy that is being ignored or insulted. Respect!

The established or so-called "authorized heritage", including World Heritage, has been criticised for not being universal or sufficiently representative. The Convention is also seen as having elevated a typical Western view of cultural and natural heritage to a general norm. In addition, it is regarded as having, in practice, favoured elite monuments and buildings in the West. History, memory, and heritage belonging to hitherto neglected nations, groups, and genders are thought to require more attention (e.g. Smith 2006: 85ff).

Lynn Meskell wants to see a more general prioritisation of living people before the stones of the past; of archaeological investigations before the preservation of monuments; and of visions of peace before technological assistance. The early, global UNESCO under the leadership of the biologist Julian Huxley was intended to be peopled by intellectuals and academics; but the organisation then developed into an intergovernmental technocracy characterised by consultants, bureaucrats, and politicians. Meskell nevertheless takes the view that UNESCO would have to be reinvented if it did not exist (Meskell 2018: 1ff, 59ff, 76, 226).

However, UNESCO, with its World Heritage General Assembly, Committee, and Secretariat, has tried to respond to the criticism. For instance, there has, in principle, been criticism of the selection of sites ever since the Convention came into practice with the listing 
of the first World Heritage sites in 1978. The uneven geographical distribution came in for particular criticism.

First, ICOMOS established a Global Study Working Group from 1989 onwards, and then, in 1994, a Global Strategy was adopted for greater representativeness, balance, and credibility. Analyses were carried out to demonstrate what was represented or underrepresented in relation to categories, chronology, regions, and themes. There was, for example, said to be an over-representation of cultural heritage in Europe, of historic towns, religious monuments, Christianity, historical periods, and "elitist" architecture. ICOMOS concluded that imbalances could be attributed to countries not having overviews of their heritage and systems for protection and preservation, as a result of which the necessary tentative lists were either flawed or not provided at all. UNESCO's strategy has therefore been to encourage, assist, and include, with a view to inscribing new alternative sites to supplement the existing ones. It therefore encouraged the establishing of new World Heritage sites within the framework of cultural landscapes, cultural routes, agricultural settlement, secular architecture, industrial heritage, and the modern period (whc.unesco.org/en/globalstrategy; WHL Filling, 2004; Operational 2019: $\mathbb{S} 554-61)$. Finally, the establishment of a convention for Intangible Cultural Heritage (ich.unesco. org/en/convention) in 2003 can be interpreted as an attempt to complement the World Heritage Convention, which was characterised by a Western material view of cultural heritage, with a new convention focusing on the intangible.

World Heritage must not only be outstanding and universal; it has to be representative too. But the equation with three variables is not unique to the World Heritage Convention. The same problems are to be found in the debate on human rights.

Intimations of human rights can be found far back in time, actually as far back as pharaonic Egypt. However, the Age of Enlightenment has been assigned a special role in the narrative of human rights, with the American Declaration of Independence in 1776 and the French Revolution's Declaration of the Rights of Man and of the Citizen in 1789 as milestones. The UN's Universal Declaration of Human Rights (1948) is usually regarded as a reaction against the atrocities of the 1930s and 1940s. The Declaration was adopted by $48 \mathrm{UN}$ member countries, while 8 abstained (Bring 2011: 11ff).

But human rights are disputed. What is at issue here is the interpretation of the Declaration's background in the history of ideas, 
the importance of individual agents, and, more specifically, different political and religious views about how human rights can, should, or must be formulated. From the very beginning, the rights were criticised for being too limited and for being too extensive. The UN Declaration has been criticised for imposing a Western norm on the countries of the world as universal. Another critical view holds that the rights may be in conflict with cultural or religious requirements. For example, the Organisation of the Islamic Conference adopted an alternative Cairo Declaration on Human Rights in Islam (1990), in which the rights are delimited in relation to Sharia (hrlibrary. umn.edu/instree/cairodeclaration.html).

Several commentators have asked whether heritage is a human right. In one instance, the answer is unclear (Kristiansen 2001: 150f), and in another, it is negative (Barthel-Bouchier 2013: 27ff). Referring to human rights may be a rhetorical strategy geared to gaining further support for heritage since, despite all the conflicts, these rights do have a relatively high international legitimacy. Even so, there is no mention of heritage at all in the Universal Declaration of Human Rights (1948). Nor is there any such mention in the Cairo Declaration on Human Rights in Islam (1990) or, for instance, in the International Covenant on Economic, Social and Cultural Rights (1966/1976).

Is World Heritage a human right? Anyone who wishes to assert that it is must also consider what that would entail. Is it the right of all groups, peoples, or nations precisely to "their" cultural and natural heritage as World Heritage? Or is it World Heritage that is a right for everyone as a collective, that is, for the whole of humanity? And in both instances, what would that mean more specifically? For instance, it may be noted that while World Heritage is laid down in a binding treaty, the Declarations may be more prestigious, but they are not binding.

There is, however, an ongoing debate precisely about the relationship between World Heritage and human rights. The debate may, for instance, deal with the fact that a World Heritage site can as such become a symbol of rights, an example being Robben Island in South Africa (WHL 916, 1999). It may also address the fact that the absence of the establishment of a World Heritage may be regarded as a violation of rights. In addition, it may be about whether the management of World Heritage sites should take account of the rights of, for example, indigenous peoples. And it may be about the fact that different principles can collide universalism, diversity, and relativism. The debate may also 
arise on account of vandalisation of World Heritage sites (e.g. Silverman \& Fairchild Ruggles 2007; Langfield et al. 2010; Logan 2012; Harrison 2013: 140ff; Ekern et al. 2015; Bille Larsen 2018; Meskell 2018: 218ff).

The relationship between the outstanding and the universal in the case of World Heritage is part of a larger debate about the particular and the general. On one side is the universalism of the Age of Enlightenment, with humanity as an imagined collective, and on the other is the particularism of Romanticism, with its emphasis on the distinctive character of specific nations, peoples, and individuals with their culture and history. We meet the latter in the preoccupation of the present with identities - who you "are", not who or what you may become.

How can the paradoxical oppositions built into the very design of the World Heritage Convention be resolved? Tentative World Heritage sites are nominated nationally, conferring national legitimacy on a proposal. Here the particular perspective is taken into account. Decisions on nomination and listing are subsequently made by international representatives in consultation with expert bodies. This amounts to considering the global perspective. Consequently, a negotiation is evolved in which the particular and the universal, the local and the global, the national and the international, try to meet. Combining several levels, World Heritage becomes "glocal", with double legitimacy (cf. Robertson 1995; also Turtinen 2006: 62). The global "product" is to a certain extent adapted to local conditions. It is a matter of the art of the possible, of diplomacy and politics, where there is give and take. A diplomatic negotiation ensues - if you accept my World Heritage, I will accept yours.

When the World Heritage Convention has been a success enveloped in practically global consensus, this is due partly to its particularly ingenious design, which unites opposites, and partly to responsive management, which has taken account of the priorities of different decades. The Convention has gained permanence through adjustments and supplements that served to modernise it - just like World Heritage itself.

What is particularly ingenious is that the Convention succeeds in embracing a number of apparent opposites: culture and nature, the particular and the universal, the local or national and the global, the popular and the elitist. For each country nominates what that country considers important. World Heritage occurs globally, but it is managed locally. And despite being steered by experts, it also 
appeals to local and popular engagement. World Heritage is of use when it comes to asserting antiquarian protection and preservation as well as national pride and identity, and it is often included in a strategy for increased tourism and growth.

Even so, the strength of the design of World Heritage, with national nominations and an international decision, is, at the same time, its weakness. States cannot have their cultural or natural heritage accepted as World Heritage against the will of the international community - and the international community cannot impose World Heritage on a country.

Just as the Universal Declaration of Human Rights (1948) may come into conflict with religious views, the World Heritage Convention (1972), as practised, may collide with the sacred in religion. This is likely to be the reason why the Kaaba in Mecca is not a World Heritage site as a building. It undoubtedly meets one or more criteria; but it has such a central role as a shrine in the Muslim world, and for Saudi Arabia, that there is no question of placing it on a tentative list. By contrast, other holy monuments, buildings, and sites are instances of World Heritage - for example St Peter's Basilica in Vatican City (WHL 286, 1984) and Durham Cathedral in England (WHL 370bis, 1986, 2008). Cultural heritage and the sacred can live in symbiosis, but not without complications, not without compromises, and not in all contexts (e.g. Clausén 2016: 95ff, 117ff). If the "sacred" in an antiquarian context competes with the sacred in a religious context, and coexistence is not possible, a choice must be made. For instance, the currents of tourists pouring into cathedrals can be seen as a problem for their use precisely as churches.

The weakness of the design also becomes visible in relation to contested heritage. Why should Poland take responsibility for Auschwitz-Birkenau (WHL 31, 1979) as a World Heritage site when it is a Nazi German facility? How can, must, or should Jerusalem be managed as a World Heritage site (WHL 148rev, 1981) when three world religions and several nations make claims on the site? And can Hebron/al-Khalil on the West Bank in Palestine be managed as a new World Heritage site (WHL 1565, 2017) in the face of Israeli protests? Conflicts in the present also become conflicts about the past.

If a map is a model of reality, a map can also reshape this reality. Similarly, reality can be shaped through written words in declarations and conventions. The World Heritage Convention shapes our view of the listed monuments, buildings, sites, and landscapes, and hence has an impact on their actual future. The Convention talks about something outstanding, universal, and representative 
for which everyone is responsible. An idea is fused with materiality, and something new is created.

\section{Exclusive World Heritage}

UNESCO's organisation of World Heritage is reminiscent of the structure of the UN, with member states that meet in a general assembly, a security council, expert bodies, and a secretariat; but there are no permanent member states that hold a veto. The member states of the Convention meet every other year for overarching discussions in a General Assembly. Decisions on inscription in the World Heritage List - and on the List of World Heritage in Danger - are made annually in the World Heritage Committee. The Committee consists of elected representatives of 21 member states, who serve on the Committee for a period of at most six years (WHC 1972: Article 8; Operational 2019: $\mathbb{\$} \$ 17-26$ ). A secretariat is required to assist the World Heritage Committee, and in conjunction with the 20th anniversary of the Convention in 1992 it was set up in a World Heritage Centre in Paris (WHC 1972: Article 14; Operational 2019: $\mathbb{S}$ 27-29; whc.unesco.org/en/world-herit age-centre). Its work is to take place in consultation with experts from the Rome Centre (now also called ICCROM), ICOMOS, and IUCN (Operational 2019: $\$ \$ \$ 30-37$ ).

UNESCO's intentions with World Heritage are explicitly stated in the Convention from 1972, and they amount to "ensuring the identification, protection, conservation, presentation, and transmission to future generations of the cultural and natural heritage" (WHC 1972: Article 4).

To achieve this aim, each of the participating countries is under express obligations pertaining to five areas:

1. to adopt a general policy which aims to give the cultural and natural heritage a function in the life of the community and to integrate the protection of that heritage into comprehensive planning programmes;

2. to set up within its territories, where such services do not exist, one or more services for the protection, conservation, and presentation of the cultural and natural heritage with an appropriate staff and possessing the means to discharge their functions;

3. to develop scientific and technical studies and research and to work out such operating methods as will make the State capable of counteracting the dangers that threaten its cultural or natural heritage; 
4. to take the appropriate legal, scientific, technical, administrative, and financial measures necessary for the identification, protection, conservation, presentation, and rehabilitation of this heritage; and

5. to foster the establishment or development of national or regional centres for training in the protection, conservation, and presentation of the cultural and natural heritage and to encourage scientific research in this field. (WHC 1972: Article 5)

On the basis of the World Heritage sites proposed by individual countries, the Committee established a World Heritage List, as well as a List of World Heritage in Danger, in respect of which active measures may be required (Article 11). In addition, a World Heritage Fund, based on both compulsory and voluntary contributions, was established to support the work of individual countries (Article 15).

The process by which something is elevated to a World Heritage site, and is entered in the list, is lengthy and involves laypeople, experts, and politicians at several levels over a good many years. The process generally starts with local lobbying work in which sites compete with one another for inclusion on a national tentative list. Each country then presents proposals drawn from this list - and the international lobbying can start or continue. As of 2018, each country will only be able to nominate one World Heritage site, and at most 35 nominations will be assessed. The decisions are made by UNESCO's World Heritage Committee once a year after receiving advice from the experts in ICOMOS and IUCN, in a process that is reminiscent of a peer-review process for the publication of academic articles and books (cf. WHC 1972; Operational 2019: $\mathbb{S} \$ 34-37, \mathbb{\$} \$ 45-95, \mathbb{S} \$ 143-151$ ).

Since 2010, nomination work has included an "Upstream Process" that provides advice, consultation, and analysis (whc.unesco.org/en /upstreamprocess). The tentative lists are public (whc.unesco.org/ en/tentativelists), and UNESCO offers guidance on how to go about the nomination itself (whc.unesco.org/en/nominations).

A fundamental point about World Heritage sites is that they have to possess outstanding universal value: monuments and buildings must have "outstanding universal value from the point of view of history, art or science", and sites must have "outstanding universal value from the historical, aesthetic, ethnological or anthropological point of view" (WHC 1972: 1; Operational 2019: $\mathbb{\$} 45-53$ ).

Outstanding value is characterised by ten criteria, and a World Heritage has to meet one or more of them. From the first instructions 
in 1977 until 2004, there were two lists of criteria - one for culture with six criteria (i-vi) and one for nature with four (i-iv). Since 2005, a common list is applicable:

(i) represent a masterpiece of human creative genius; (ii) exhibit an important interchange of human values, over a span of time or within a cultural area of the world, on developments in architecture or technology, monumental arts, town-planning or landscape design; (iii) bear a unique or at least exceptional testimony to a cultural tradition or to a civilization which is living or which has disappeared; (iv) be an outstanding example of a type of building, architectural or technological ensemble or landscape which illustrates (a) significant stage(s) in human history; (v) be an outstanding example of a traditional human settlement, land-use, or sea-use which is representative of a culture (or cultures), or human interaction with the environment especially when it has become vulnerable under the impact of irreversible change; (vi) be directly or tangibly associated with events or living traditions, with ideas, or with beliefs, with artistic and literary works of outstanding universal significance. (The Committee considers that this criterion should preferably be used in conjunction with other criteria); (vii) contain superlative natural phenomena or areas of exceptional natural beauty and aesthetic importance; (viii) be outstanding examples representing major stages of earth's history, including the record of life, significant on-going geological processes in the development of landforms, or significant geomorphic or physiographic features; (ix) be outstanding examples representing significant on-going ecological and biological processes in the evolution and development of terrestrial, fresh water, coastal, and marine ecosystems and communities of plants and animals; $(\mathrm{x})$ contain the most important and significant natural habitats for in-situ conservation of biological diversity, including those containing threatened species of Outstanding Universal Value from the point of view of science or conservation. (Operational 2019: $\mathbb{\$} \$ 77-78$ )

Moreover, a monument, building, or location has to have integrity and/or authenticity, adequate protection, and a management system to ensure its safeguarding.

The document Operational Guidelines for the Implementation of the World Heritage Convention (2019) supplies a detailed presentation, description, and definition of everything conceivable with a connection to World Heritage - the Convention, the participating countries, the General Assembly and Committee, the Secretariat, advisory bodies, the definition of World Heritage, representativity, balance and credibility, tentative lists, assessment criteria, integrity and authenticity, protection and management, the process 
of preparations for nomination containing format and content, requirements, registration, evaluation, withdrawal and decisions, modifications to the boundaries of World Heritage properties or of the criteria used, the timetable, reactive monitoring, the List of World Heritage in Danger with guidance, criteria, and evaluation, reporting on the implementation of the Convention, encouraging support for the Convention in the form of awareness-raising, education, and research, information about the fund and international assistance, the World Heritage emblem, sources of information, forms, and a bibliography.

The emblem and plaques may be mentioned as an example of the degree of detail in the Operational Guidelines. A thorough account is given of the World Heritage emblem, setting out its meaning and proper use in a large number of sections (Operational 2019:

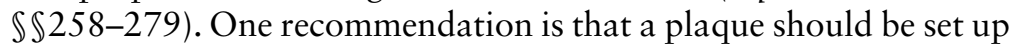
at every new World Heritage, and there is a description of where it should in that case be placed and how it should be designed, including a suggestion regarding the wording on it (Operational 2019:

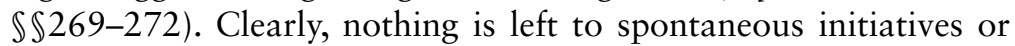
to chance.

The purpose of this extremely carefully established process, all the instructions and documents, must be twofold: first, to generate rational uniformity and predictability in assessment and management; second, to bestow international legitimacy on the Convention and the World Heritage Centre and hence also on the World Heritage List.

The number of new World Heritage sites listed each year has varied all the time. In the first year, 1978, 12 World Heritage sites were listed in 7 countries. The fewest, a mere 7, were listed in the politically turbulent year 1989, whereas the largest number, 61, was listed in the year 2000. Of the 1121 World Heritage sites that have been listed in 167 countries, 869 are cultural, 213 natural, and 39 mixed (WHL; overview July 2019; Appendix 1).

A World Heritage site can be justified by several criteria. For example, the Nubian monuments from Abu Simbel to Philae were justified by three criteria - i, iii, and vi (WHL 88; 1979). By making searches in the World Heritage List, it is possible to obtain statistics about the use of criteria. The distribution is as follows: criterion $\mathrm{i}$ is found in $254(22.7 \%)$ of all 1121 World Heritage sites, ii in 449 $(40.1 \%)$, iii in $466(41.6 \%)$, iv in $597(53.3 \%)$, v in $157(14.0 \%)$, vi in $246(22.9 \%)$, vii in $146(13.0 \%)$, viii in $93(8.3 \%)$, ix in $128(11.4 \%)$, and $x$ in $156(13.9 \%)$. In other words, the cultural 
criterion iv occurs most often and natural criterion viii least often (WHL; statistics July 2019).

In a broad sense, World Heritage sites may be said to be representative of heritage and the past. World Heritage covers all periods of human history; and as is the case with cultural heritage, there is a gradual shift so that modern monuments, buildings, sites, and landscapes are also being included in the List to a greater extent. Geographically, World Heritage sites have spread to most of the earth, even though (so far) not all countries that have acceded to the Convention have their own World Heritage sites. And thematically, World Heritage represents a wide range of nature and culture (Operational 2019: $\$ \$ \$ 54-61)$. The wording of the criteria also shows that World Heritage sites have to be representative (i) and to act as "examples" of something greater (iv, v, viii, ix) (Operational 2019: \$77). Different regions and cultures in the world have to be represented on the World Heritage Committee (WHC 1972: $\$ 8: 2$ ).

Paradoxically, however, while all World Heritage sites are part of cultural or natural heritage, they differ from it on several key points - in their definition, process, growth, and need for protection. Cultural heritage and natural heritage are therefore both more and less than World Heritage.

Unlike cultural heritage, which is an open and expansive concept that can cover all tangible and intangible expressions of human influence, World Heritage is a well-defined concept reserved for monuments, buildings, and sites that meet one or more set criteria. But World Heritage may, at the same time, be something different from cultural heritage, since it also covers outstanding and universal natural heritage.

While everyone is perfectly free to claim that something is heritage, the requirements for becoming a World Heritage are formalised in a particular way. The organisation and process surrounding World Heritage has been laid down to the very last political, economic, legal, and bureaucratic detail. There are an international World Heritage Convention, a World Heritage Committee, a Secretariat at the World Heritage Centre, Operational Guidelines that have been adjusted numerous times, a large number of directions and reports, meetings, conferences, and a website containing masses of additional information, statistics, and references.

And while the concept of heritage can grow freely, while more and more is constantly being seen as heritage, the increase in the number of World Heritage sites is strictly regulated. Each year, an 
announcement is made as to how many new World Heritage sites have been inscribed.

At first sight, the importance of threats and destruction in justifying protection would seem to be something that heritage and World Heritage have in common. The very first lines of the Convention formulate the need for its existence by referring specifically to threats: "Noting that the cultural heritage and the natural heritage are increasingly threatened with destruction not only by the traditional causes of decay, but also by changing social and economic conditions which aggravate the situation with even more formidable phenomena of damage or destruction ..." (WHC 1972: 2, italics in the original; also Operational 2019: \$4).

Further on, the Convention specifies possible examples of threats in connection with the establishment of a separate List of World Heritage in Danger:

the threat of disappearance caused by accelerated deterioration, large-scale public or private projects or rapid urban or tourist development projects; destruction caused by changes in the use or ownership of the land; major alterations due to unknown causes; abandonment for any reason whatsoever; the outbreak or the threat of an armed conflict; calamities and cataclysms; serious fires, earthquakes, landslides; volcanic eruptions; changes in water level, floods, and tidal waves. (WHC 1972: Article 11.4; also Operational 2019: $\$ \$ 177-191$ )

The temples of Abu Simbel were threatened in the 1950s by the modernisation of Egypt, by the Aswan High Dam and by the higher water level in the Nile; but when Nubian monuments from Abu Simbel to Philae became a World Heritage site in 1979 (WHL 88, 1979), they were no longer threatened. And this is typical of the great majority of monuments, buildings, places, and landscapes listed as World Heritage sites. For even though threats are stressed as a justification for the Convention, the tentative World Heritage sites are rarely if ever threatened. They generally belong to the heritage category that has long come in for national, and often also international, attention. Inscription is more of a final confirmation of a pre-existing canonisation as something outstanding and universal. But why categorise something as World Heritage to be protected for the future if it is already protected? What is the need for a convention for the protection of World Heritage sites with reference to threats, if these threats have no real existence?

To understand and explain World Heritage as a phenomenon, I want to focus on the points where World Heritage differs from 
heritage. The paradoxical relationship between heritage and World Heritage is the very place to look for an answer, because while heritage is open, informal, and expansive, World Heritage is bounded, formalised, and regulated. While everyone is entitled to assert a heritage, experts determine what will be World Heritage. Everything can be heritage, whereas World Heritage is something outstanding and exclusive. And if heritage should, just like World Heritage, be protected, it can be noted that World Heritage is protected already.

If we look at what the Convention does not explicitly express but what it actually does, it distinguishes an extremely exclusive group of cultural heritage and natural heritage sites as something exceptional. While Sweden, for example, has thousands of cemeteries filled with memorials, only one of them, the Woodland Cemetery (Skogskyrkogairden) in Stockholm, has been made a World Heritage site (WHL 558rev, 1994). The Woodland Cemetery is outstanding.

The canonical exclusiveness of World Heritage is also clear to see in a report produced by the Swedish National Heritage Board: Sweden has 15 World Heritage sites, 43 cultural reserves, 264 listed government buildings, 1647 museums, 1650 national interests for cultural environment protection, 2266 listed non-government buildings, 3422 protected churches, 30,011 buildings marked in municipal plans for their heritage value (but this statistic is based on information from only 11 of 21 counties/regions), 283,669 ancient monuments, 595,872 other cultural heritage remains, and a total of 7,608,094 buildings (Räkna med kulturarvet, 2017: 7). Summarised as a simple and instructive statistic, there are thus 507,206 buildings for every World Heritage site in Sweden.

The Convention creates a category separated from the mass of heritage. When a gradual democratisation of heritage has created inflation in the concept, a new category, managed by an elite, is introduced. When everything can, in principle, be designated as heritage, a carefully selected part is given certified status as World Heritage. The devaluation of the heritage concept leads to the establishment of a new currency. The establishment of World Heritage can therefore be interpreted as a compensatory response to the inflation in heritage.

The Convention establishes a hierarchy of values that not only has consequences for the handling of the remains of the past, but also confers social status on the countries, institutions, and individuals involved. The Convention has created what may be called a "distinction", to use a concept borrowed from the sociologist Pierre 
Bourdieu (1979 (French); 1984 (English)). Consequently, World Heritage is not (only) about protection and preservation; it is (also) about distancing.

In order to be able to manage the World Heritage sites and maintain hierarchical distance, no depreciation of their value can be permitted. This makes it essential to have sharp definitions, specific criteria, a difficult process, and a regulation of their growth. Here UNESCO's World Heritage Centre, with its Committee, functionaries, Convention, and Guidelines, functions as a gatekeeper. Rejections of applications are essential to maintain the standard, and any potential threats must be given careful consideration: the outstanding must not become too general (e.g. Batisse 1992: 30). Still, it is difficult to maintain a distance. Innumerable monuments, buildings, places, and landscapes are competing to become World Heritage sites. And sites that do become World Heritage rise in popularity, so that the frequently desired tourism becomes a new menace.

However, it is inconsistent when the journalist Peter Hanneberg regrets the tourism and the inflation in the number of World Heritage sites - cultural ones in particular - while writing frequently in the media about trips to World Heritage sites and publishing coffee-table books lavishly illustrated with photographs geared to augmenting interest in them (Hanneberg 1998; cf. 2012). And it is inconsistent, or at any rate problematic, when the local level has hopes of increased tourism while increased tourism may become a threat.

This brings to mind the Nobel Prize for Literature, an exclusive distinction for something and someone already honoured; there, however, the distinction is accompanied by a cash reward. And for 50 years, secrecy shrouds who was nominated and exactly how the discussion went, unless somebody breaks their obligation to remain silent...

\section{Modern World Heritage}

You can be a World Heritage site; but if you are, you must be modern too. World Heritage as both a concept and a reality can be surprisingly modern. And if World Heritage is not modern to begin with, it can be brought into modernity through modernisation, management, and representations. On the face of it, World Heritage is expected to be remains of the past to be protected and preserved for the future - monuments such as the temples of $\mathrm{Abu}$ 
Simbel. But World Heritage as a concept and as a collection of actual sites does not by any means represent the past only. The very categorisation as World Heritage, with its Convention and management, is a modern phenomenon. And in the course of the process of being accepted as World Heritage - or, subsequently, as a consequence of that acceptance - a World Heritage is irretrievably thrown into a modernity characterised by change, renewal, and movement.

Most cultural World Heritage sites are of an impressive age, measured in centuries or millennia. The natural World Heritage sites may even be of an age that can be measured in millions of years, for instance the Grand Canyon in the US (WHL 75, 1979) and the Dolomites in Italy (WHL 1237rev, 2009), at the same time as nature with its plants and animals is constantly being recreated in the present. But modernity is also abundantly represented, with more than 50 World Heritage sites from the eighteenth, nineteenth, and twentieth centuries. They include sites that mark crucial historical events, the architecture of modernism, and the infrastructure of industrialism with its bridges, tunnels, canals, railways, and factories.

The first modern World Heritage site on the list is also perhaps the most controversial one, namely Auschwitz-Birkenau (WHL 31, 1979) of 1940-1945, which became a World Heritage site in 1979, the second year of listing. The problematic character of the site is indirectly shown by the fact that the UNESCO list officially gives it a supplementary designation as a "German Nazi Concentration and Extermination Camp" - not a Polish camp, even though it is geographically located in Poland, and not just "German" either. The question of where the camp belongs is a disputed issue. On good grounds, neither Poland nor democratic Germany wants to recognise the site as "its" heritage. Otherwise, Germany is known and recognised for its Vergangenheitsbewältigung, that is, its exertions to deal with a problematic past (e.g. Dudek 1992). In 2018, Poland adopted a law that imposes a sentence of imprisonment for up to three years for calling Auschwitz-Birkenau a "Polish death camp". As a World Heritage site, Auschwitz-Birkenau can represent a modern epoch, a site of crimes against humanity that must not be forgotten - and according to Zygmunt Bauman a modern rational (death) industry (Bauman 1989).

The next modern example is less controversial and represents the emergence of revolutionary ideas. It is Independence Hall, or Pennsylvania State House (WHL 78, 1979), which also became a 
World Heritage site in 1979. The building is not primarily being preserved for its style, which is Georgian. The reason for the building's status is that it is where the Declaration of Independence and the US Constitution were signed, in 1776 and 1787 respectively.

The first example of modern uncontroversial industrial heritage as World Heritage is the Ironbridge Gorge (WHL 371, 1986) in England, with its bridge erected in 1779. The subsequent decades saw the addition of a large number of modern World Heritage sites - the capital city of Brasilia (WHL 445, 1987), Bauhaus in Weimar, Dessau, and Bernau (WHL 729bis, 1996, 2017), the Hiroshima Peace Memorial (WHL 775, 1996), Zollverein Coal Mine Industry (WHL 975, 2001), Mountain Railways of India (WHL 994ter, 1999, 2005, 2008), White City of Tel Aviv (WHL 1096, 2003), Grimeton Radio Station (WHL 1134, 2004), Central University City Campus at UNAM in Mexico (WHL 1250, 2007), 17 buildings by the architect Charles-Édouard Jeanneret, known as Le Corbusier (WHL 1321rev, 2016), Bikini Atoll Nuclear Test Site on the Marshall Islands (WHL 1339, 2010), Japan's Meiji Industrial Revolution (WHL 1484, 2015), Asmara: a Modernist City of Africa (WHL 1550, 2017), eight buildings by the architect Frank Lloyd Wright (WHL 1496rec, 2019) - and many more.

The youngest World Heritage so far is the architect Jørn Utzon's Sydney Opera House (WHL 166rev, 2007), erected in the period 1957-1973. The Sydney Opera House represents modernism, is an icon of Australia's largest city, and became a World Heritage site in 2007.

But it is probably only a matter of time before a monumental construction work in the present - such as the Millennium Wheel from 1999, also called the London Eye - achieves World Heritage status. Another candidate might be the "Bird's Nest", as Beijing's National Stadium at the 2008 Olympic Games is known; the artist Ai Weiwei was involved in its design, but his political activism may prove an obstacle. As yet, none of these examples appears on a tentative World Heritage list.

In fact, most of the World Heritage sites - or, at any rate, most of the cultural ones - may be connected to the concept of modernity, since they were once modern in the sense of constituting something new in their own present. For example, one of the very first World Heritage sites on the list is Chartres Cathedral (WHL 81bis, 1979, 2009) in France, where the Gothic building style of the twelfth century was an expression of bold new ideas about light, form, and technology. Another example that was modern in the sense of being 
a technical innovation is the Ottoman Stari Most (Old Bridge) in Mostar (WHL 946rev, 2005) in Bosnia-Herzegovina. When Stari Most was opened in 1566, its free span across the Neretva River was supposedly the broadest ever. In Walter Benjamin's words, every epoch has been able to feel modern (Benjamin 1983 (German): 2, 677; 1999 (English): 545).

If a World Heritage site is not already modern, it can be modernised so as to remain relevant and useful. For example, a good many sites have been renewed or substantially restored in order to even come under consideration as World Heritage. Others have been modernised or given modern additions as a result of their listing. Notably, many World Heritage sites have had to build parking places, paths, and visitor centres, and many have been illuminated so as to be able to attract or regulate an expected or actual increase in tourist numbers.

Like other examples of heritage, World Heritage sites are managed by antiquarian and environmental authorities in a process called heritage management. In the canonical tradition of heritage, there is a continual production of manuals, journals, articles, reports, courses, and conferences about how heritage can, should be, or is managed in relation to threats, protection, preservation, and accessibility, with general recommendations, instructions, and examples adapted to the legislation of different countries or to international conventions (e.g. Leask \& Fyall 2006).

The World Heritage Centre has, for instance, published a series of manuals for the management of World Heritage sites, covering what are termed "Disaster Risks" and referring to both natural and cultural World Heritage (whc.unesco.org/en/managingcultural-world-heritage). And the World Heritage List contains a careful presentation, under the heading "Protection and management requirements", of what antiquarian regulations apply in each individual case and what action is going to be taken (WHL). The concept of management refers to principles for leading operations or organisations that are, as such, typical expressions of rational modern society.

Wooden buildings in Asia may be perceived as old and authentic, even though they have been renewed a number of times. Here authenticity is linked not to the materiality in itself, because wooden structures are often replaced, but to the preservation of the craft tradition and architecture, which amounts to applying a view of authenticity that differs from what is traditional in the West (Byrne 1995; Larsen 1995). One example is found in the World Heritage 
site in the previous capital Kyoto in Japan. This site comprises wooden buildings and gardens from the tenth century up to and including the sixteenth; but both buildings and gardens have been fully or partly renewed since they were first constructed (WHL 688, 1994).

However, constant change and renewal are not unique to an "Asian" way of thinking. Continuous management also occurs as a strategy in the West in the form of repeated restorations, full or partial reconstructions, and other interventions. At the World Heritage site of Stonehenge (WHL 373bis, 1986, 2008), stones were raised again and secured throughout the twentieth century; a nearby road with heavy traffic has been closed; footpaths and car-parking spaces have been created; and 2013 saw the opening of the new Stonehenge Visitor Centre, placed further away from the monument than its predecessor (Chippindale 2012; www.englishheritage.org.uk/visit/places/stonehenge).

At the Acropolis in Athens (WHL 404, 1987; Beard 2010; Sandis 2014: 57ff), the Classical period has been given priority with the temple of the Parthenon, which is intended to legitimise the Greek State. In 1834, only a few years after the country's new-won independence, the Parthenon was opened as an ancient monument and as a symbol of the young nation. During the subsequent decades, the Acropolis was "liberated" from buildings or ruins that were not from Antiquity - traces of the Parthenon as a Byzantine or French cathedral or as an Ottoman mosque, Roman and Florentine remains, and Turkish settlements. A restoration of the ancient Acropolis has been under way since 1975, and its justification as a World Heritage site puts special emphasis on the Classical period. A new Acropolis Museum was opened in 2009, to provide more room for the many tourists visiting the site and to act as a setting for a long-sought-for return of the Parthenon frieze (also known as the Elgin Marbles) from the British Museum (e.g. Melotti 2011: 191ff). Another example is Jelling (WHL 697, 1994, 2018; Hvass 2000; 2011) in Denmark, where the buildings in the railway-station community around grave mounds, rune-stones, and the church have been bought up and removed since the 1910s, so as to be able to uncover the monuments - not without conflicts with local people who wanted to protect business and trade. A nearby visitor centre called Kongernes Jelling was built in 2000 and has since been renewed. Shortly after the act of graffiti vandalism in 2011, in the course of which "GELWANE" was painted on the largest stone, both rune-stones were placed in outdoor display cases. The 
excavated remains of a large ship-setting, a palisade, and halls were marked clearly in concrete in 2013. The whole area now looks like a gigantic outdoor installation from the 2000s.

In a few cases, the character of modern restorations and reconstructions has itself been sufficient to justify the status of a site as a World Heritage site. This applies, for instance, to Warsaw, where more than $85 \%$ of the historic centre of the capital city was destroyed during the rising in 1944, but where the city centre was practically reconstructed in full during the period 1945-1984 (WHL 30bis, 1980, 2014; Appelbom Karsten 1987: 72ff). Another example is the Fortified City of Carcassonne (WHL 345rev, 1997) in France, which was threatened with demolition but where the architect Eugène Viollet-le-Duc succeeded in carrying out an extensive restoration in 1853-1879, which was continued after his death. Viollet-le-Duc's modern restoration is an important reason why Carcassonne was made a World Heritage site.

In addition, there are World Heritage sites that have not yet been completed but where the construction process is under way. For instance, seven works by the architect Antoni Gaudí (WHL 320bis, 1984, 2005) became World Heritage sites in Spain in 1984. However, the church of La Sagrada Familia in Barcelona, which was started in 1882 and where Gaudí had time to contribute to the crypt and the facade before his death in 1926, is not expected to be (largely) completed until 2026.

A renewal in the form of a reconstruction or a radical restoration may also be taken into consideration when a World Heritage site has been destroyed in war or through acts of terrorism. For example, the Stari Most bridge in Mostar (WHL 946rev, 2005; Nikolic 2012: 53ff) in Bosnia-Herzegovina was fired on and destroyed by Croatian artillery in 1993; but it was reconstructed and reopened in 2004 as a symbol of reconciliation, cooperation, and coexistence. Mausoleums in the World Heritage in Timbuktu (WHL 119rev, 1988) in Mali, which were destroyed in 2012, are being reconstructed as well. By contrast, the reconstruction of the Buddha statues in Bamiyan in Afghanistan, which were both destroyed in 2001, has been abandoned (WHL 208rev, 2003).

However, the lack of any great measure of consistency in dealing with the reconstruction, restoration, and modernisation of World Heritage sites is clear from the different positions that are taken from site to site. For instance, the Dresden Elbe Valley (WHL 1156, 2004, delisted 2009) in Germany became a World Heritage site in 2004. Dresden, with its baroque architecture, was largely destroyed 
in bomb raids in 1945. After the reunification of Germany, the Frauenkirche (Church of Our Lady) was reconstructed in the period 1994-2005, as were parts of the surrounding buildings from the eighteenth century. The World Heritage site also includes modern industrial heritage with bridges, a cableway, and a railway; one example is the Loschwitzer Bridge, also called the "Blaues Wunder" ("Blue Wonder"), a steel bridge from 1891-1893. But when a new motorway bridge of steel and concrete, the Waldschlösschen Bridge, was planned in order to reduce city traffic, it was a bridge too far. The World Heritage Centre warned that Dresden risked being removed from the World Heritage List and proposed building a tunnel instead. A referendum was held, as were court hearings, but work on the bridge continued. Dresden Elbe Valley was placed on the List of World Heritage in Danger in 2006 and was removed from the World Heritage List in 2009. Or, to be correct, it still appears on the list; but now it is firmly crossed out as a reminder that it has been discredited. The new bridge was opened in 2013 .

The temples of Abu Simbel are excellent examples when it comes to illustrating a modern World Heritage site. With their style and size, the temples constituted something new in the Nubian frontier region in their pharaonic present. They were rediscovered and investigated in what has been classed as the modern epoch, in which the past as well as territories were colonised by European great powers. Nature was to be tamed so as to modernise postcolonial Egypt as well. The Aswan High Dam and the power stations would compel the waters of the Nile to produce electricity, and the annual floods would be regulated. But the dam project created a lake that threatened the temples of Abu Simbel and other remains of the past. Modernity threatened heritage. The solution was a gigantic salvage campaign, a feat of engineering that lifted the temples above the rising water mirror of the Nile (The Salvage of the Abu Simbel Temples 1976: 200). The temples were brought into modernity as reconstructions at nearby new sites. They were "reborn" into a modern time and a modern society.

The temples of Abu Simbel were cut up, moved, and reassembled using modern science and technology under arched domes of concrete and hidden in artificial hills. The temples were illuminated both internally and externally, and their interior was given modern ventilation. Modern buildings, hotels, roads, and an airport were constructed nearby (The Salvage of the Abu Simbel Temples 1976; Säve-Söderbergh 1987; 1996). The salvage action was regarded as an international success, which paved the way for the phenomenon 
of World Heritage - and for Nubian monuments from Abu Simbel to Philae to become a World Heritage site as early as 1979, the second year of listing (WHL 88, 1979). The temples were thus adapted to Egyptian tourism, in which visitors could be driven, sailed, or flown to the site. It was a development in which the first European adventurers and the select few who had travelled along the Nile in earlier times paved the way for latter-day mass tourism encouraged by travel guides, (crime) novels, film, and advertising.

There was a modernisation of Abu Simbel in the world of representations too. There is a technological development from the first drawings and watercolours to the photographs of the $1850 \mathrm{~s}$, the film of the 1900s, and the 3D scans of the twenty-first century. Pictures of the temples were mass-produced and widely disseminated. In 1959, before the cutting and relocation, the temples were also documented by photogrammetry (Desroches-Noblecourt \& Gerster 1968; The Salvage of the Abu Simbel Temples 1976: 33, 72 with Fig. 13.1:1). The temples can be visited virtually, sitting in front of a computer screen. In the virtual world, too, the temples can be reconstructed digitally and coloured to give viewers an experience of their original appearance (e.g. Siliotti 1997). Today, the drawing pad, the easel, and the relatively slow technology of the photographic apparatus have been replaced by a smartphone, in which tourists at the site are able to instantly share images and films from their visit with other people all over the world. Obviously, representation is also subject to the acceleration of modernity.

The reconstruction of Abu Simbel included careful planning of how the temples would be illuminated both internally and externally. First and foremost, the great temple was orientated so that the sun could continue to penetrate to the statues in its interior twice a year, as before. Then artificial lighting was created, lighting that would on the one hand permit studies and on the other hand imbue the temples with a "mysterious and sacred atmosphere" (The Salvage of the Abu Simbel Temples 1976: 191f with Fig. 20: 1). The light was thus intended to permit both the clarity of knowledge and the enchantment of beauty.

In this respect, Abu Simbel is only one of numerous World Heritage sites whose dark interiors have been made accessible to the scrutiny of human eyes by means of artificial lighting, and whose exteriors are illuminated at night in order to create an experience, and perhaps also as a preventive measure for protection. Abu Simbel, Auschwitz-Birkenau, Independence Hall, the Ironbridge Gorge, the Sydney Opera House, Chartres, the Bridge in Mostar, 
Timbuktu, the Acropolis, Jelling's rune-stones, Warsaw, Carcassonne, and La Sagrada Familia - all are floodlit at night, whereas this is not normally the case at Stonehenge or Bamiyan. Light moves World Heritage into modernity.

\section{Destination World Heritage}

The Past is a Foreign Country! We often employ metaphors in order to describe our relationship to the past. We travel - or escape - to or from another time or another country. In nostalgia, a home country or a lost time is being missed. People also travel more tangibly to monuments, buildings, and places that represent the past. But why do we travel to seek out the past?

The temples of Abu Simbel were destinations from the very moment of their construction; they must have required a great inflow of labour. Greek graffiti from 592 вCE on the legs of the statues of Ramses II, the name of the adventurer Belzoni from 1817, and other inscriptions are memories of numerous visits (MacQuitty 1965: 76, 84, 91, 98f, 134; DesrochesNoblecourt \& Gerster 1968: 30f). After their rediscovery, the temples became destinations on cruises along the Nile. Travel books, novels, and films established Abu Simbel as Egyptian icons along with destinations including the Museum of Egyptian Antiquities, the pyramids of Giza, the Valley of the Kings, Karnak, and Luxor; upper-class travel paved the way for mass tourism. The salvage campaign of the 1960s increased the attraction of the temples by means of a new narrative, and the construction of a town, hotels, roads, an airport, and a port made even more visits possible. Inscription on the World Heritage List along with other Nubian monuments between Abu Simbel and Philae (WHL 88,1979 ) only confirms the importance of the temples as tourist destinations.

The World Heritage List contains numerous other sites that have been destinations for centuries. They include places of religious pilgrimage, for instance Jerusalem (WHL 148rev, 1981), St Peter's Basilica in Rome (WHL 286, 1984), and Santiago de Compostela in Spain (WHL 347, 1985). Another is Venice in Italy (WHL 394, 1987), which became a destination at an early date. Most World Heritage sites were established tourist destinations long before being entered on a tentative national list, nominated, and inscribed. Even so, most destinations for pilgrimage or tourism are of course not World Heritage sites. 
The linking of tourism and World Heritage is not a matter of chance. Established World Heritage sites are usually already important destinations. And when nominations are made, there is often a local hope that the new World Heritage site will become a destination that attracts more visitors and therefore promotes development and economic growth in the local area. World Heritage sites are "modernised"; that is, they are adapted to the needs of the tourist industry with signage, illumination, visitor centres, paths and trails, and car parks.

However, UNESCO's ambition for World Heritage sites is not limited to development and the economy. According to the anthropologist Michael A. Di Giovine in The Heritage-scape (2009), UNESCO's aim is to create a new global system and a new global identity with the aid of World Heritage sites. UNESCO wants (or wanted) to create a borderless and peaceful world (cf. also Meskell 2018).

At the same time, there is constant criticism of tourism to World Heritage sites. That criticism stresses how World Heritage sites themselves are adversely affected by commercialisation and wear and tear from mass tourism. The effects of the many visitors on the local population and the surroundings are a factor too.

At such destinations as the Ironbridge Gorge in the UK (WHL 371, 1986), Visby in Sweden (WHL 731, 1995), and Venice in Italy (WHL 394, 1987), the point is made that the gradual transition to heritage and World Heritage has led to a gentrification, in other words a change of the social mix in the area. Conflicts of interest may also arise between the local population, newcomers, and tourists (e.g. Ronström 2007; White \& Devlin 2007). For example, in the summer of 2017, there were demonstrations in Venice against mass tourism and its consequences. The city now has more tourists every day than it has permanent year-round residents. The World Heritage site with its souvenir shops has become a threat to modern city life, with its need for shops for convenience goods. But gentrification of attractive urban environments in recent decades is a widespread phenomenon, not solely the preserve of World Heritage; and it began long before the concept of World Heritage had been devised.

UNESCO has worked actively to regulate tourism at World Heritage sites in the awareness that it can have both benefits and drawbacks. For instance, strategies were formulated at an early stage for "sustainable" tourism that works with, and not against, the local population (World Heritage Sustainable Tourism Programme, 2001; Bourdeau et al. 2015; 2017; whc.unesco.org/en/tourism). 
If one wishes to claim that the primary purpose of World Heritage is to create tourist destinations, the response will be that the great majority were destinations already. But listing has undoubtedly served to attract more attention. The sites become part of an international branding exercise. But why, then, do people visit the past at all?

In The Great Museum (1984), Donald Horne compared heritage tourism in Europe to medieval pilgrimages, museums to churches, exhibited objects to relics, and tourists to pilgrims - and many others have thought along the same lines. The attraction is the perception of authenticity in a period of modernity, industrialism, crisis, and nervousness. But tourism is extensive, and it is growing swiftly, irrespective of whether the present can be characterised as modern or postmodern, as bearing the stamp of industrialism or deindustrialisation. Tourism is growing in Europe; and it is growing in China as well. Everywhere people are given the opportunity to travel - sufficient freedom, leisure, money, and health - they go and visit other places. Tourism is growing because more and more people are being given the opportunity to travel, something that used to be the preserve of a few.

There is no single reason to travel, no single reason to visit World Heritage sites. At this point, I would again like to invoke the triad of truth, beauty, and goodness. Travel to the past can engender new knowledge, contribute to the forming of new experiences, and make reflection possible.

\section{Enchantment and expectations}

World Heritage is everywhere. While the list, when started in 1978, consisted of 12 World Heritage sites in seven countries, there are now 1121 World Heritage sites in 167 countries (WHL, July 2019). But why does a special category called World Heritage exist in the first place, and why did the temples of Abu Simbel become World Heritage sites?

UNESCO's World Heritage Convention came into being in 1972 in order to protect and preserve monuments, buildings, and sites that possess "outstanding universal value" for future generations. To justify this need, the Convention refers to increasing and new threats to cultural and natural heritage (WHC 1972: 1). In other contexts, the campaign at Abu Simbel in the 1960s is highlighted as an important background, since threatened monuments were salvaged through international cooperation (e.g. Batisse 1992; 
whc.unesco.org/en/convention). Nubian monuments along the Nile from Abu Simbel to Philae were listed as World Heritage site in 1979, with the criteria of being (i) a masterpiece (ii) testimony to a vanished civilisation, and (vi) an open-air museum that represents the unfolding of a long sequence of Egyptian pharaonic history (WHL 88, 1979).

The temples of Abu Simbel are undoubtedly masterpieces and represent a vanished civilisation; but are they not already lost, at least partly? For salvaging the temples from drowning meant that they had to be broken up, relocated, and reconstructed at a new site under concrete arched domes in artificial hills. So the temples became World Heritage despite debatable authenticity. The temples of Abu Simbel appear as they did at the time of Ramses II, but are largely the result of a modernisation in the 1960s.

Several other World Heritage sites mix old and new. The wooden buildings in Kyoto in Japan have been renewed repeatedly (WHL 688, 1994); the Fortified City of Carcassonne in France was substantially renewed in the nineteenth century (WHL 345rev, 1997); and Warsaw in Poland was reconstructed after the Second World War (WHL 30bis, 1980, 2014). Here, too, continued permanence was achieved through radical changes where that which appears, at first sight, to be from Antiquity - or to be pre-modern - may in fact be modern.

The past is indeed everywhere; for the whole of our present, everything in our "now", has been accumulated from parts of various ages. The present consists of innumerable "archaeological" layers in a complicated stratigraphy. The view from my remembered or current office is composed of parts, some of which have existed for centuries while others are modern; and the view is in constant change. But in point of fact, this present, this now, is also already past, since it takes time for my senses to register and coordinate the impressions into an interpretation in my brain (Eagleman 2016: 52f). Consequently, we can state that the past is everywhere and that this is, in itself, not problematic.

The composition of my view depends on where I am and where I direct my gaze. It also depends on how my surroundings are affected over time in the course of interplay between humans, culture, and nature, with an ongoing building up and breaking down. In archaeology, this is called taphonomic or formation processes.

What survives from the past to the present, what gains permanence - the temples of Abu Simbel, for example - depends on which materials were used from the outset, on forces of nature 
including the climate and weather at the location, and on human interventions such as clearing from sand after rediscovery. The choice made by Pharaoh Ramses II to have the temples carved out in the rock has ensured permanence for thousands of years. And the campaign in the 1960s ensured further permanence into the future when the Aswan High Dam brought the threat of flooding and destruction, but it was a permanence that entailed radical changes.

In an analogy with evolution, what has survived until today may be described as a process of selection in which only the useful survives. The past with its history, memory, and heritage survives until the present if the prerequisites for permanence exist thanks to the choice of durable materials or favourable conditions for preservation. And it is not sufficient to have an environment that counters natural degradation; the past also has to be useful in the present, and that is why it comes in for attention and is told about, remembered, and protected. That which is not "of use" will be ignored, go undocumented, be forgotten, or be allowed to decay. At the same time, every retelling, recalling, or preservation involves a change on the part of that which is to remain. This is why nature is not alone in "developing"; history, memory, and heritage do so too.

With another analogy, the past is a landscape of ruins from which spolia are gathered that may be moved to new places and given a new use. History, memory, and heritage are invested with new meanings as the issues and needs of the present shift. The past may thus be used for the true, the beautiful, and the good - and for the false, the ugly, and the evil. With this perspective, nostalgia is not a longing for a lost or "foreign country", but a hunt for narratives that can be reused. Lowenthal's books, with their innumerable examples and contradictory interpretations, are precisely that kind of quarry, where everyone can find something that suits whatever they may be building. That is the reason for their attraction and popularity, despite Lowenthal's critical attitude.

That the past is everywhere is nothing to be surprised about. For heritage to suddenly be everywhere is a completely different matter. If heritage is everywhere - or if everything can be heritage that means that everything should also be protected and preserved. The ultimate consequence of such a principle is that all change, all renewal, is forced to cease. This is not realistic. So how did the perception that heritage is everywhere arise?

The inflation in the demand for preservation is a consequence of the acceleration of change. The phenomenon has been given many 
names - modernity, supermodernity, late capitalism, the great acceleration, or a completely new period in which the impact of humans dominates around the globe, the Anthropocene epoch. Since the industrialisation of the nineteenth century, continuing during the twentieth century, since the Second World War, and especially since the 1970s, with more countries sharing in modernity, the speed of change has increased. The quantity of accumulated past - and the rate of turnover of this past - has grown.

Asserting heritage everywhere and for everything is a compensatory and psychological reaction to the great acceleration. Nor is this reaction illogical, since experience shows that remains of the past can be useful now or at some time in the future in contexts that we cannot predict. But since everything cannot be preserved and protected, because then society would ossify, several methodological and overlapping strategies can be discerned.

One established strategy is to prioritise and only preserve selected parts, whereas other remains are allowed to disappear with or without documentation. An archaeological excavation does not document everything, just as not all finds are transported for exhibition or storage in museums. Similarly, priorities are set among narratives, memories, and heritage sites. These priorities are, in principle, assigned on the basis of what the present finds relevant; that is, useful. Speculation about what might become relevant in the future occasionally forms part of this process.

But the preservation of original remains of the past in libraries, archives, and museums for future use is under pressure, since it is costing more all the time. There is, however, a rapid development of (relatively expensive) digital methods for documentation and reconstruction. We can hence envisage ever more remains being documented and preserved digitally, so as to be recreated later as required. With a less "Western" and more "Asian" attitude to authenticity, this would be a strategy that could be combined with a continuation of the rapid developments in this area.

Prioritisation can be combined with creative reuse, in which heritage is modernised so as to remain relevant. Monuments, buildings, sites, and landscapes can be given new functions and meanings. Abu Simbel becomes a tourist destination, while industrial heritage buildings become offices, homes, or hotels. In my view, this extensive "management" amounts to a strategy in which cultural and natural heritage are deliberately adapted to the present - not least tourism.

Still, it is also possible to choose not to tell, not to remember or preserve. Here two different attitudes meet: the futurists, who 
want to confirm progress, modernity, and the future, so away with the remains of the past, and the romantics, who want to leave well alone and contemplate the beauty of decay or decline, so let the remains of the past go away naturally. From widely different starting points, they arrive at attitudes that have the same consequences the disappearance of heritage.

The World Heritage Convention is a modernist strategy for prioritisation and management, so that the outstanding and universal is protected and preserved for the future while being adapted to the ideological and economic needs of the time. World Heritage is thus a compensatory reaction both against the great acceleration and against the subsequent inflation in heritage. The Convention and its highly organised bureaucracy recreate order, hierarchy, and distance. But if there is inflation in World Heritage as well, then the process may start again with the creation of new priority categories.

Should the temples of Abu Simbel go, so that progress is not impeded, or should they be blown up or drown? No: when the modernisation of Egypt with the Aswan High Dam formed a threat, the choice that was made was an international salvage campaign which also partly modernised the temples, so that they continued to be of use. Otherwise, both futurists and romantics would have been able to look on while the faces of Ramses II slipped below the water's surface day by day - either relieved to be rid of the past or reflecting pensively on what had disappeared.

Abu Simbel represents cultural heritage; but the same attitudes can, in principle, be transferred to natural heritage: prioritise, document, modernise, root out, or leave be. If it is part of modernity to distinguish between nature and culture, the opponents of modernity have some explaining to do if they want to treat (the heritage of) culture in one way and (the heritage of) nature in a completely different way. For modernity is, after all, a human creation, and as such it is also a consequence of a "natural" development.

The World Heritage Convention represents order, hierarchy, and distance in relation to proliferating heritage. At the same time, though, listing as a World Heritage adds something invisible. The special elevated and distanced status of World Heritage as outstanding and universal may be described as a modern "enchantment", or something sacred in a more or less secularised modern world. This is why World Heritage as a phenomenon may be compared with the sacred in the religious sphere. In both spheres, the enchanted represents different perspectives and narratives that may both coexist and collide. 
Not unexpectedly, there is enormous faith in World Heritage; it is expected to be able to work miracles - or it is blamed for erroneous deeds. Either World Heritage is expected to contribute to greater knowledge, growth, diversity, and peace, or World Heritage is held responsible for abuse, mass tourism, gentrification, and destruction. World Heritage becomes a projection plane for the hopes and frustrations of the present. And either it is not possible to have enough of history, memory, heritage, and especially World Heritage - or there is already far too much.

But why focus so much on history, memory, and heritage? Why not focus on modernity instead? The main problem may, for better or worse, be that "modernity is everywhere". 


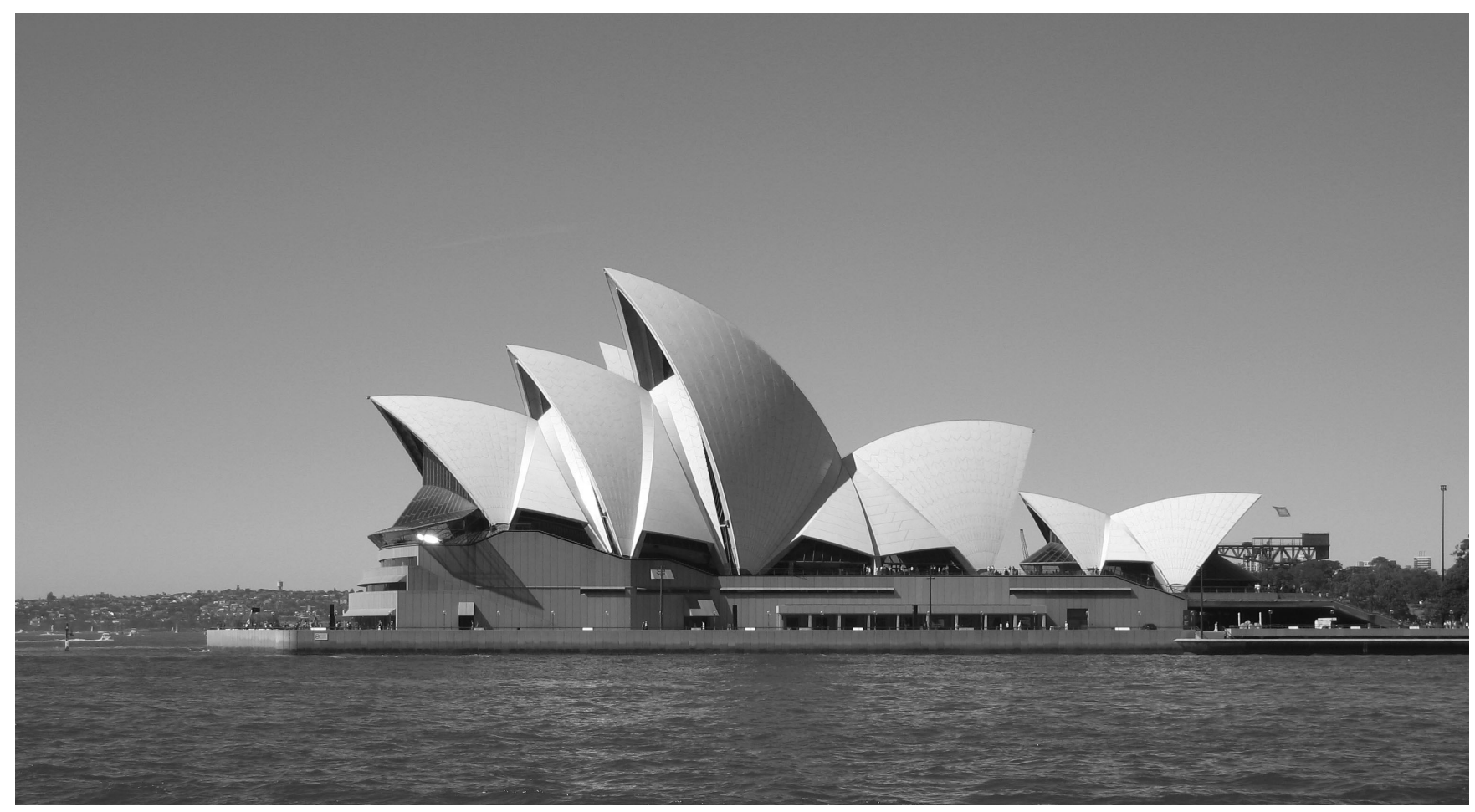

Figure 7 Sydney Opera House. Photo @ Anders Andrén, 2006. 